\title{
How to Promote International Competitiveness of China's Renewable Energy Products? - Based on SNA Theory
}

\author{
Wei Qi, Hanyu Xiong*, Xiaoya Peng \\ School of Economics and Management, North China Electric Power University, \\ \#619 Yonghua Street, Baoding China
}

Received: 4 October 2020

Accepted: 18 November 2020

\begin{abstract}
The depletion of resources and environmental pollution caused by excessive consumption of fossil energy has made the development and utilization of renewable energy the focus of the world. This paper uses social network analysis method to analyze the network characteristics of global trade of renewable energy products, and empirically studies the factors of trade network formation through QAP method. The results showed that: (1) Each node country has a close relationship in the global trade network of renewable energy products, and the spatial pattern shows heterogeneity; (2) In the renewable energy product trade network, Germany, the United States and China At a clear core position, some European countries are semi-marginal, some developing countries and emerging economies are gradually emerging; (3) Economic scale, geographical proximity, technological factors and regional trade relevance to trade in renewable energy products The formation of the network structure has a positive impact, but the degree of impact on different products varies significantly.
\end{abstract}

Keywords: renewable energy, social network analysis, network topology, Core-edge structure, QAP empirical analysis

\section{Introduction}

Renewable energy has attracted worldwide attention because of its ability to achieve a balance between effective supply and clean utilization, and better ensure the stable and healthy development of the economy. Since the founding of the People's Republic of China, the renewable energy industry has undergone tremendous changes from small to large, from a single model to

*e-mail: distance818@163.com diversified production. The key technological progress is remarkable, and the industrial strength is gradually increasing. According to the International Renewable Energy Agency, in terms of trade, in 2019, among the top 10 global module manufacturers in terms of shipments, Chinese photovoltaic companies accounted for eight seats. Chinese module manufacturers shipped $67.6 \mathrm{GW}$, accounting for about $70 \%$ of the total global shipments. In addition, polysilicon, silicon wafers, cells, components, inverters and other products produced in China account for $58.1 \%, 91.5 \%, 74.8 \%, 72.8 \%$, and $62 \%$ of the world's products respectively. There is no doubt that China has developed into the world's leading 
manufacturing and utilization of renewable energy equipment. In recent years, China's technological innovation ability and technological equipment independence ability of renewable energy-related industries have been significantly improved. However, there is still a gap between China and developed countries.

With the gradual deepening of the international division of labor, the industrial characteristics of high added value and high technology content have become the main signs of judging the size of national competitiveness. At present, researches on the trade of renewable energy products were mainly focused on the calculation of indicators that characterize competitiveness. Most scholars used international market share (MSI), trade competitiveness index (TC), trade specialization index (TSI) and other indicators to measure the competitiveness of renewable energy products at a specific point in time or a specific period. For example, Fu J., Sun J, the researches of the above two authors were concentrated in the solar energy and wind energy industry, they used the Porter diamond model and the measurement of trade characteristics to illustrate the trade competitiveness of the renewable energy industry. They analyzed and concluded that China's solar and hydropower industries have certain trade competitiveness, and the ocean energy and geothermal energy industries The trade pattern needs to be improved, and corresponding policy recommendations have been put forward $[1,2]$. Veena Jha studied the classification of renewable energy commodities and the development trend of the industry based on the HS code, He provided a reference system of statistical indicators for subsequent trade studies of renewable energy products [3]. Shuai et al. used the CMS model to analyze the dynamic changes in the international competitiveness of Chinese renewable energy products. They analyzed that the absolute increase in export volume conceals the essence of the decline in the international competitiveness of products [4]. In addition to using index analysis methods, Ming $\mathrm{L}$ et al. Using the conditional variance of the export growth rate and the GARCH model, it overcame the influence of time series fluctuations, and discussed the competitiveness of renewable energy products from different perspectives. [5]. Scholars were also very concerned about the factors that affect renewable energy trade. In terms of methods, there were mainly gravity models (Liu M., Wang X.), general equilibrium models (Boehringer $\mathrm{C}$ et al.), non-uniform panel models (Kim K et al.) [6-8]. The application of these models and methods is of reference significance for subsequent research. After all, they are important tools commonly used in econometric analysis. However, if we simply apply the above methods to study the factors affecting the trade network structure of renewable energy products, it is lack of innovation. By constructing an index evaluation system, Chen X. Y., Wang Z.W. used analytic hierarchy process and principal component analysis to quantify influencing factors [9]. The above researches provided a definite reference for the analysis of trade issues in renewable energy products. However, it has also been shown that merely relying on statistics based on the amount of trade and calculating corresponding indicators based on this did not reflect the changes in the status of each country in the trade pattern. At the same time, these studies have failed to systematically explain the relationship between the renewable energy industry, namely equipment manufacturing and trade, from the perspective of global trade network linkages.

Social Network Analysis (SNA) is a method of constructing a complex network, extracting core subnets based on trade weights, and analyzing the relationship structure and attributes among the nodes. Snyder and Kick first used SNA method to analyze the characteristics of the world economic system [10]. Subsequently, Serrano M., Fagiolo G., Baskaran T., et al., Ma S.Z., et al. studied the network structure characteristics and dynamic evolution of different products in international trade [11-14]. The main research objects were commodities, agricultural products, etc. So there were not many articles that analyzed renewable energy products from the perspective of social networks. Among them, Dong G.G., et al. investigated the supply network structure of traditional fossil energy crude oil trade, and obtained the optimal network structure with the smallest transaction cost by simulating the distributed two-party network of trade. They provides new ideas for subsequent studies on the stability of trade structure in other industries [15]. Xi X., et al. also discussed the impact of changes in the crude oil trade mode of countries along the "Belt and Road" and their position in the trade network on the GDP of each country based on complex networks and econometric theories [16]. However, there were few articles analyzing renewable energy products from the perspective of social networks. Guan et al. analyzed the trade status of major trading countries by building an international photovoltaic product trade network from 2000 to 2014 [17]. Ji built a world trade competition network for photovoltaic products and analyzed the intensity and evolution of photovoltaic export trade competition in major countries [18]. Zhang G.P., et al. used wind power's cross-border trade data to build an international trade network and examined the role of trade networks in determining the spread of wind power technology among various countries [19].

To sum up, there were few articles that comprehensively analyzed the structural characteristics of the trade network of renewable energy products. At the same time, they only emphasized the role characteristics of some manufacturing powers in the trade network, and lack the core-peripheral structure of the trade network of renewable energy products. Therefore, it did not consider the role of different types of countries in terms of the characteristics of trade direction. The analysis of influencing factors is mostly 
based on the descriptive analysis of trade motivations, and there are few studies considering QAP analysis from the matrix level.

Does the continuous expansion of China's renewable energy product production scale and export scale also mean the continuous improvement of our country's related product competitiveness? With the deep integration into the renewable energy global value chain system, what is the degree of embedding and structural characteristics of China? In order to get the answer, this article used the statistical data of the United Nations Commodity Trade Database to construct a product trade network formed by major countries that trade renewable energy in 2018 based on Veena Jha's classification of renewable energy trade commodities. Meanwhile, the SNA method is used to analyze the network topology characteristics of the global trade of renewable energy products, and quantify the factors that affect the formation of the trade network, so as to accurately position the international division of labor in China's renewable energy industry, with a view to changing well tap the market potential and development space of the industry. This can accurately position the international division of labor in my country's renewable energy industry, let the policy makers and enterprises better tap the industry's market potential and development space.

The above content explained the research background of this article and the current researches status of related issues, as well as the current application fields of the selected research methods. The rest of the paper is organized as follows. Section 2, we will introduce the relevant theories of social network analysis and the data sources and processing steps required for research. Section 3, we will carry out the calculation and result analysis of trade characteristic indicators. The rest part, section 4 will be used to organize the structure of the article and draw conclusions and related policy recommendations.

\section{Material and Methods}

\section{Research Methods of Social Network Analysis}

The above content explains the research background of this article and the current research status of related issues, as well as the current application fields of the selected research methods. The second part will introduce the related theories of social network analysis and the data sources and processing steps required for research.

\section{Construction of Trade Networks of Major Global Countries for Renewable Energy Products}

Trade value outflow country is taken as the starting point, the point is represented by the sector $V_{\mathrm{i}}=\left[v_{i}\right]$, $(i=1,2,3, \ldots, n)$ Taking the destination country of trade value as the target node, expressed by vector $V_{j}=\left[v_{j}\right],(j=1,2,3, \ldots, n)$, The value of trade from country $i$ to country $j$ is represented by $W=\left\{w_{i j}\right\}$, the adjacency matrix $A=\left[a_{i j}\right],(i=1,2, \ldots, n)$ is used to represent the connection between the starting and target countries. This global trade network of renewable energy products can be described as $\mathrm{G}=\left(V_{i}, V_{j}, A\right)$, among them

$$
A=a_{i j}=\left\{\begin{array}{l}
1, \text { if } w_{i j}>0 \\
0, \text { otherwise } w_{i j}<0
\end{array}\right.
$$

\section{(1) Closeness Centrality}

Closeness Centrality is calculated as the sum of the shortest distance from one point to all other points, and the value reflects the degree to which the countries represented by the nodes rely on the transmission function of other nodes in the GVC network of renewable energy products. The calculation formula is as follows:

$$
C_{R P i}^{-1}=\frac{C_{A P i}^{-1}}{g-1}
$$

The degree of absolute closeness is $C_{A P i}^{-1}=\sum_{j=1}^{n} d_{i j}$, The number of lines contained in the shortcut between node $i$ and $j$ is expressed as $d_{i j}$, The greater the relative proximity to the center, the farther the distance from the center, the weaker its influence and control ability on other countries in trade relations.

(2) Betweenness Centrality

The degree of betweenness centrality measures that the country represented by the node is located in the path of many cross networks. It measures the degree to which a nodal state, as an actor, controls resources or information and trade routes. The calculation formula is as follows:

$$
C_{R B i}=\frac{2 \sum_{j}^{n} \sum_{k}^{n} b_{j k}(i)}{g^{2}-3 g+2}, i \neq j \neq k \& j<k
$$

Under (2), $2 \sum_{i}^{n} \sum_{k}^{n} b_{j k}(i) \quad$ is the absolute betweenness centrality, $b_{j k}(i)$ is a representative of the level of association between country $j$ and country $k$ controlled by country i. $b_{j k}(i)=m_{j k}(i) / m_{j k}, m_{j k}$ is the number of shortcuts between country $j$ and country $k, m_{j k}(i)$ is the number of shortcuts that exist in the network through country $i$.

\section{Core-Periphery Analysis}

Core-edge theory is a theory proposed by John Friedman (1996) to explain the evolution pattern of economic spatial structure. This theory can usually 
explain how the points between regions develop in isolation from each other, then become interconnected, unbalanced, and finally interrelated and balanced regional system. With the development of economic globalization, the core-edge theory is often used to analyze the status of countries in the trade of different products in international trade issues. The distinction between core-edge makes the primary powerless network be converted into node connections with weights through calculation, thus creating a trade network with more analytical value.

\section{Analysis of Factors Influencing Trade Network Structure Based on QAP Method}

QAP (Quadratic Assignment Procedure) is a method of correlation determination based on matrix data substitution by comparing the similarities of the values of lattices in two squares and calculating the correlation coefficients between the two matrices. We were able to overcome the difficulty of multivariate regression analysis based on least square method (OLS) in testing the relationship between variables by using QAP regression analysis. With the help of the quadratic assignment program, this method studies the regression relationship between multiple matrices and one matrix, and can deal with the autocorrelation problem of these relational data well, thus producing unbiased results.

With reference to the research on existing trade influencing factors, the following factors are selected to explore their influence on the formation of a global trading network for renewable energy products. Therefore, using the export trade value of each country as the dependent variable matrix, construct the independent variable matrix from the following dimensions (see Table 1) and use Ucinet to quantify the relationship between each factor and the trade network.

\section{Data Sources}

This article selected the countries with the highest export share of renewable energy products in 2018, including the United States, Japan, Germany and other 33 countries, mainly distributed in Europe, Asia and the Americas. Meanwhile, this paper refers to the definition of renewable energy products by Veena Jha (2009) and Shuai Jingcheng et al. (2018). The research object is solar energy, wind energy, water energy, biomass energy, geothermal energy and Marine energy. A total of 81 tradable products were involved in the sample, including 17 solar products, 19 wind products, 17 hydroenergy products, 18 biomass energy products, 8 geothermal products and 2 Marine energy products. Trade data for the products were obtained from the United Nations Database on Merchandise Trade (UN Comtrade Database), and related data under the HS classification method are used.

As shown in Fig. 1, the dark regions in Fig. 1 are the countries and regions with large-scale development and utilization of renewable energy products in the world. Exports of renewable energy products come mainly from Asia, Europe and the Americas. The export volume of renewable energy products from these countries accounts for $70 \%$ of the world's total. The export volume of renewable energy products from the selected node countries accounts for more than $60 \%$ of their respective exports to the world. Asia accounts for $45.71 \%$, Europe $38.37 \%$, and America 15.10\%. Therefore, it is valuable to analyze the trade network formed among these 33 countries and the role played by each node.

The specific process for the analysis of the structure, structural characteristics and influencing factors of the renewable energy product trade network structure is as follows. (see Fig. 2).

\section{Results and Discussion}

\section{Structural Characteristics Analysis of Renewable Energy Products Trade Network}

\section{Degree and Intensity Distribution of Major Trading Countries}

According to statistics, China, Germany, the United States, Japan, South Korea, the Netherlands, India and other countries rank top in the total trade volume of renewable energy products. To compare the development advantages of each country in the trade

Table 1. Selection of variables and data sources.

\begin{tabular}{|c|c|c|}
\hline The variable name & Explanation & Data Sources \\
\hline $\begin{array}{c}\text { Economies of scale among trading } \\
\text { nations(R) }\end{array}$ & $\begin{array}{c}\text { The GDP value of country } i \text { and country } j \text { is multiplied, and then the av- } \\
\text { erage value of the product value of each row of the matrix is calculated, } \\
\text { which is greater than the average value of } 1 \text {. Instead take } 0\end{array}$ & $\begin{array}{c}\text { World Bank } \\
\text { Website }\end{array}$ \\
\hline Geographic proximity(G) & $\begin{array}{c}\text { Country } i \text { and Country } j \text { are adjacent to each other and share a common } \\
\text { boundary. Otherwise, take } 0\end{array}$ & CEPII Database \\
\hline $\begin{array}{c}\text { Technical factors(T) } \\
\text { Degree of regional trade } \\
\text { correlation(A) }\end{array}$ & $\begin{array}{c}\text { If the difference of per capita GDP between country } i \text { and country } j \text { is } \\
\text { greater than the mean value of each row, then take } 1 ; \text { Instead take } 0\end{array}$ & $\begin{array}{c}\text { World Bank } \\
\text { Website }\end{array}$ \\
\hline $\begin{array}{c}\text { To sign the relevant trade agreement between Country } i \text { and Country } j, \\
\text { take } 1 \text {; Otherwise, take } 0\end{array}$ & $\begin{array}{c}\text { WTO-RTA Da- } \\
\text { tabase }\end{array}$ \\
\hline
\end{tabular}




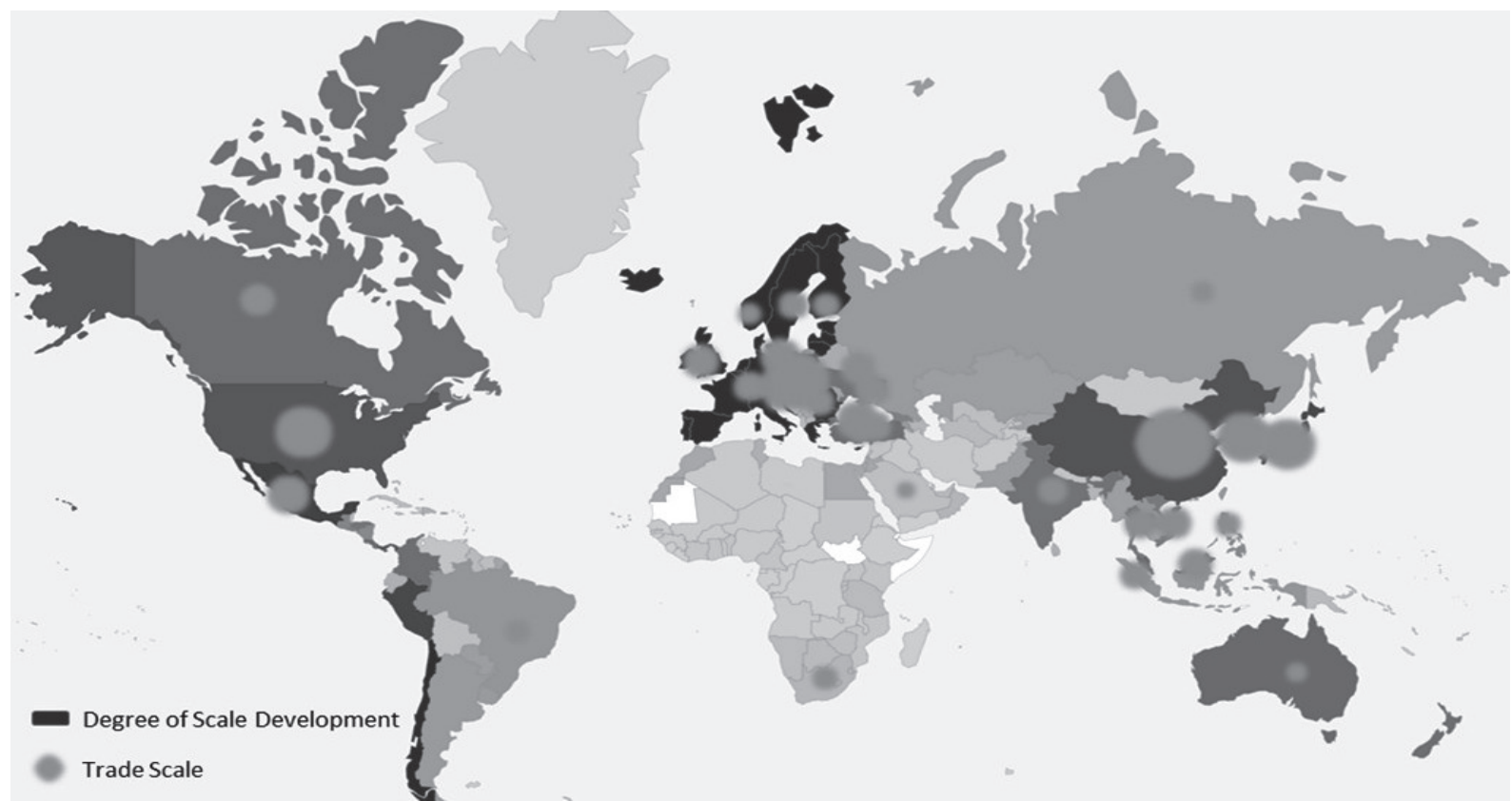

Fig. 1. Distribution of major trading countries for renewable energy products.

Note: According to trade data, a bubble chart is drawn to reflect the main renewable energy product trading countries.

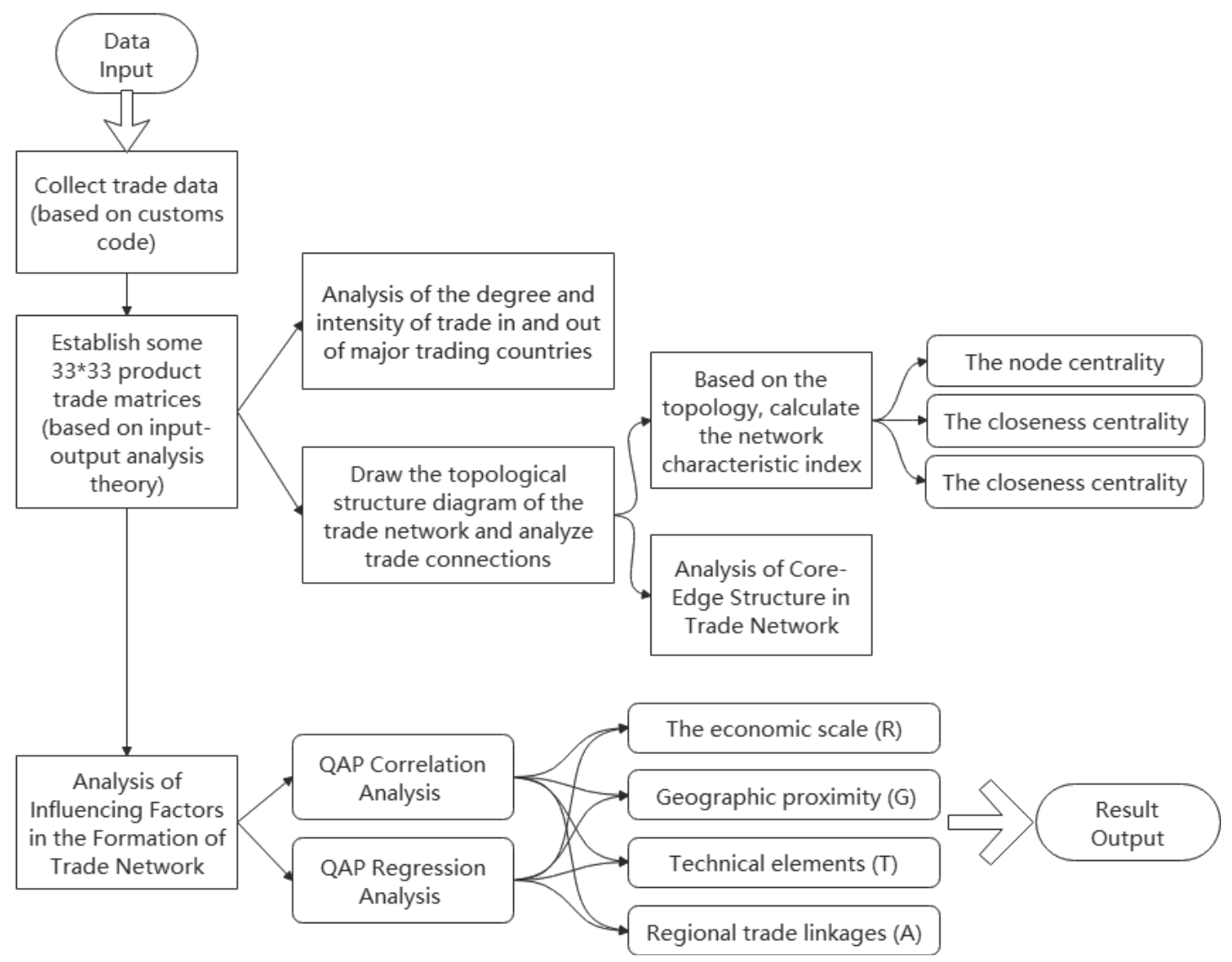

Fig. 2. Analysis flow chart of trade network structure characteristics and influencing factors.

Note: The above part mainly uses Ucinet, Gephi and other software to draw the topological structure of the trade network, and calculates various indicators and QAP analysis through the relevant functions of the Ucinet program 
Table 2. The outdegree of the seven major trading countries for renewable energy products in 2018.

\begin{tabular}{|c|c|c|c|c|c|c|c|}
\hline Indicator & \multicolumn{9}{|c|}{ Output degree (unit) } \\
\hline Country & CHN & DEU & USA & JPN & KOR & NED & IND \\
\hline The solar energy & 211 & 205 & 202 & 160 & 170 & 218 & 179 \\
\hline Hydro energy & 199 & 180 & 168 & 110 & 126 & 152 & 140 \\
\hline Wind energy & 206 & 201 & 197 & 181 & 173 & 197 & 183 \\
\hline Biomass energy & 200 & 103 & 187 & 167 & 162 & 197 & 183 \\
\hline Geothermal energy & 185 & 172 & 160 & 118 & 93 & 161 & 125 \\
\hline Ocean energy & 199 & 175 & 168 & 106 & 130 & 163 & 147 \\
\hline
\end{tabular}

Note: Calculated based on data from the UN Comtrade Database.

Table 3. The output intensity of seven major trading countries of renewable energy products in 2018.

\begin{tabular}{|c|c|c|c|c|c|c|c|}
\hline Indicator & \multicolumn{7}{|c|}{ Out strength degree (Millions of U.S dollars) } \\
\hline Country & CHN & DEU & USA & JPN & KOR & NED & IND \\
\hline The solar energy & 74852.28 & 14897.07 & 12908.58 & 12352.99 & 20778.35 & 4886.07 & 1591.48 \\
\hline Hydroenergy & 4664.81 & 3105.96 & 1562.01 & 401.38 & 660.09 & 596.27 & 548.89 \\
\hline Wind energy & 27099.22 & 30707.49 & 15815.79 & 13701.35 & 4498.81 & 2979.49 & 2492.84 \\
\hline Biomass energy & 8659.02 & 18986.34 & 15493.99 & 8302.95 & 6452.91 & 3194.96 & 1658.54 \\
\hline Geothermal energy & 2761.77 & 2706.32 & 1448.71 & 1090.7 & 784.46 & 443.03 & 350.06 \\
\hline Ocean energy & 5844.07 & 3369.05 & 3231.21 & 967.28 & 1573.50 & 524.45 & 436.38 \\
\hline
\end{tabular}

Note: Calculated based on data from the UN Comtrade Database.

network for renewable energy products, the trade degree and trade intensity of the countries represented by the nodes in the trade network are analyzed (see Table 2 and Table 3).

In terms of trade output, vertical comparison shows that China, Germany, the United States and the Netherlands have high output of solar energy products, while Japan has high output of wind energy products, while South Korea and India have high output of biomass energy products. This shows that the development of the renewable energy industry is easily subject to objective factors such as geographic location, climate, environment, etc. So it presents different product structures and development trends among different countries. From a horizontal comparison perspective, the most advantageous trade outflow is the Netherlands. The outflow of each series of products is high. The United States ranks second. The world-leading level of renewable energy technology in the United States has created its important position in the global trade network. In recent years, China has gradually entered the ranks of renewable energy power, and has achieved good results in many fields such as solar energy, wind energy, marine energy. Not only the trade network of renewable energy products is expanded, but also the status and role in the international division of labor is also increasing.
From the perspective of trade intensity, China's solar, hydro, wind and ocean energy products all have obvious advantages. Germany's advantageous projects are reflected in wind energy and biomass energy. The United States is reflected in biomass energy and ocean energy. Japan In solar energy and biomass energy, South Korea and the Netherlands are embodied in solar energy, and India is in wind energy products. All countries have shown their respective advantages. In summary, in the ranks of countries that are superior in renewable energy trade, there are not only developed countries, but also developing countries like China and India that do not have technological advantages.

\section{Network Topology of Import and Export Trade Among Major Trading Countries}

According to the preliminary out-degree and outstrength analysis, it can be seen that the distribution of the main trading countries of global renewable energy products and their product advantages, but the global trade network map is difficult to highlight, such as degree indicators, community structure, coreedge and other important network topology features. Considering that the weight of the edges that constitute trade links between nodes will affect the composition of the network, this paper constructed a $33 \times 33$ trade value 


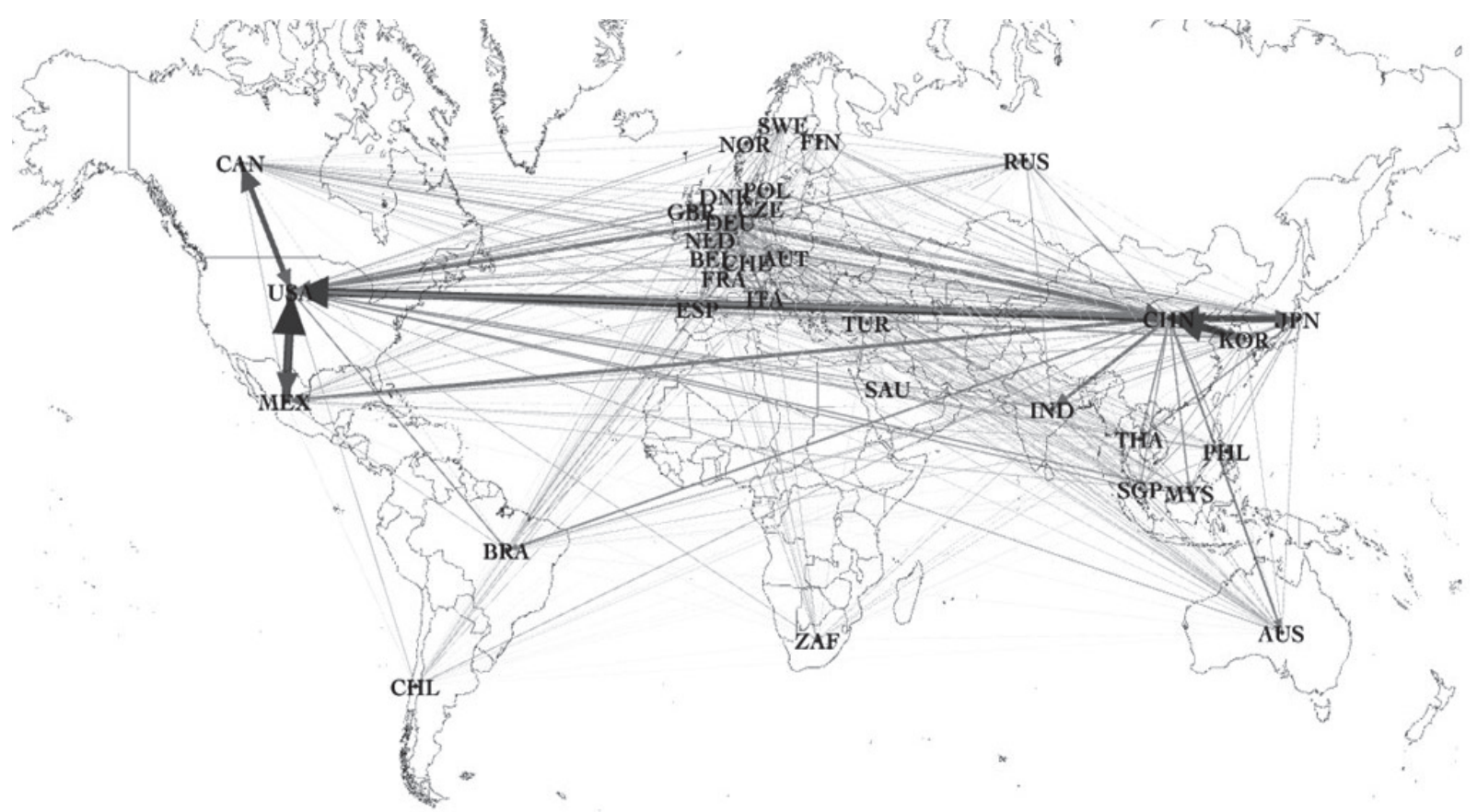

Fig. 3. Topological structure of the national network of renewable energy product trade countries in some countries in 2018.

Note: Reorganized and calculated the amount of trade in renewable energy products between trade-related countries, drawn by Gephi.

matrix $j$, the topological structure diagram of the trade network is drawn by the drawing tool Gephi.

As shown in Fig. 3, from the point of view of the total value of product trade, the American countries such as the United States, Canada, and Mexico have relatively close product trade links, and have established trade links with greater weight with Asian countries such as China, Japan, and South Korea. These countries' export is greater than the import in the trade of the product. Their product manufacturing strength is ahead of that of other countries, so they mostly play the role of product supplier. On the contrary, South Africa, The Philippines, Chile, Thailand and other node countries which are the important product demand-side

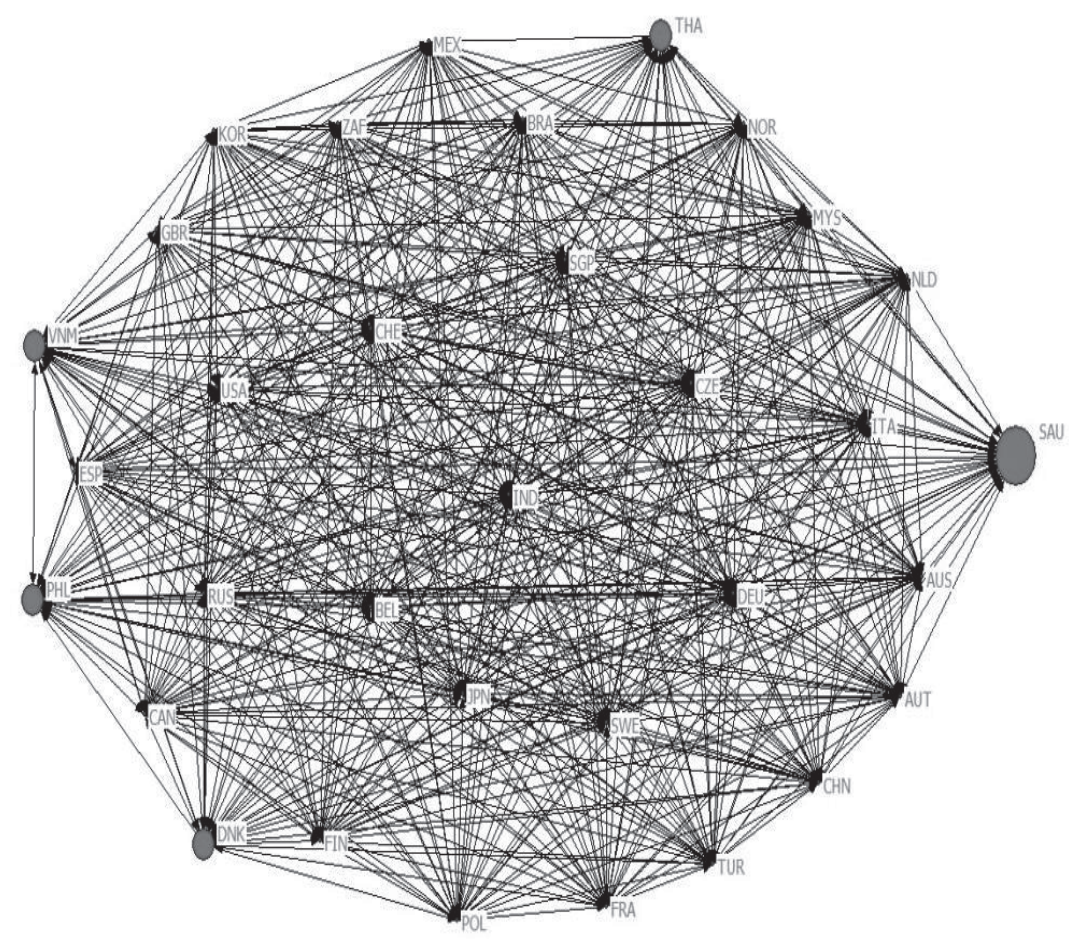

Fig. 4. The closeness centrality of major trading countries for renewable energy products. 
in the trade network because their import is greater than export. Then we calculated the node centrality of each country in the trade network. China ranks first with 17.683, the United States ranks second with 14.837, Germany ranks third with 12.340, Japan, Mexico and South Korea ranks 5.860, 5.373 and 5.288 ranked fourth to sixth, they are important roles in the global trade network of renewable energy products. In contrast, the node centralities of the Philippines, Norway, Finland, Saudi Arabia, South Africa and Chile are 0.806, 0.730, $0.667,0.572,0.479$ and 0.365 , respectively.

Then we calculated the closeness centrality and betweenness centrality, and plotted the network topology corresponding to the degree characteristics, made a preliminary observation on the core-edge characteristics of the trading network node countries.

As shown in Fig. 4. Among the major trading countries of renewable energy products, Vietnam, Thailand, the Philippines, Denmark and Saudi Arabia have a high closeness centrality, a high degree of dependency through other countries, and a low efficiency of direct transmission between them and the core countries. From the visualization of betweenness centrality, we can see that the indicator of the United States, Russia, Belgium, Singapore, Germany, Japan, Sweden and other countries are relatively high (see Fig. 5), and located on many trade paths between node countries, it plays an important role in the global import and export trade. China, South Korea, The United Kingdom, Norway and other countries also have a certain degree of control over the flow of trade. Thailand, Chile, the Philippines, Saudi Arabia and other countries have a low degree of betweenness centrality and are more controlled than other node countries.

\section{The Core - Edge Analysis of Trading Countries for Renewable Energy Products}

By analyzing the structural relationship between "position" and "role" in the nodes of the trade network, the hierarchical attributes of the country represented by the trade node can be clarified. The results shown that the degree and intensity of nodes in the renewable energy product trade network are positively correlated, with marine energy products performing the strongest, and the correlation coefficient is 0.749 . Followed by solar products $(0.647)$, water energy products $(0.575)$, wind energy products $(0.562)$, biomass energy products (0.495) and geothermal energy products $(0.324)$, you can see the global trade energy product network of different series of renewable energy. Based on the coreedge structure, the specific core edge distribution is as follows:

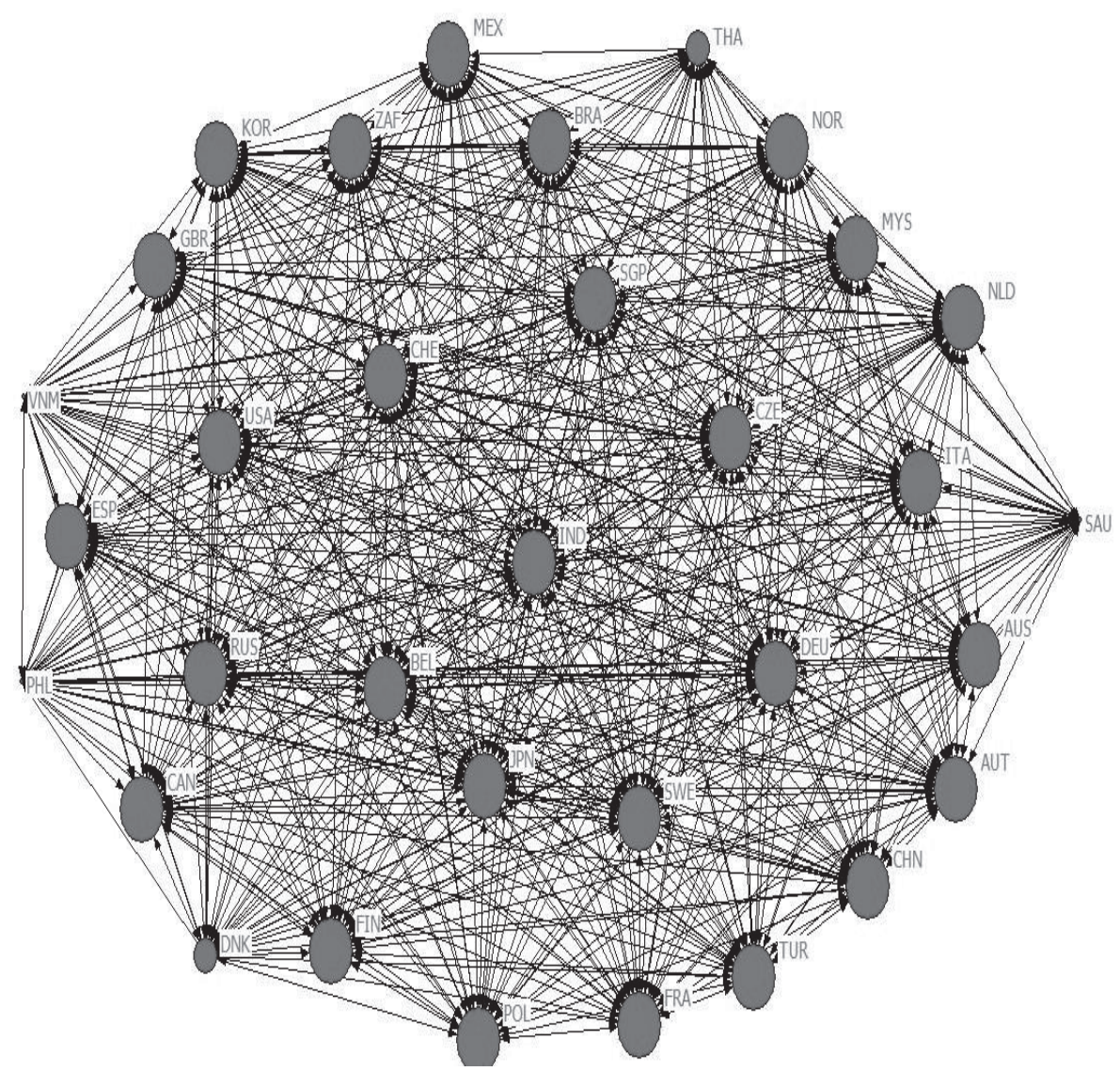

Fig. 5.The betweenness centrality of major trading countries for renewable energy products.

Note: Calculate proximity centrality and intermediary centrality through Ucinet and draw network topology diagrams. 
As we can see from the Table 4, the core countries are Germany and the United States, and later China. Due to lack of natural resources, Germany has been committed to saving energy, improving energy efficiency, and accelerating energy transformation. Its renewable energy industry has developed rapidly. The United States has not only realized the industrialization development of renewable energy, but also continuously optimized its energy structure with the vigorous implementation of environmental protection energy policy. As a result, the US trade in renewable energy products is at the core of the international trade network. Japan started late in the field of solar and wind power generation, but its production technology is still ahead of many countries. In recent years, China has put forward and implemented the renewable energy strategy, and the industry has achieved remarkable development results. It is located at the center of the trade network in the export of solar, wind and hydro energy products as well as related products of biomass and Marine energy. Other European countries, such as the UK and France, are pioneers in the development of renewable energy industry. Depending on the regional correlation of the EU and their own industrial technology base, they have their own trade competitive advantages in different products.

In the ranks of semi-marginal countries in the trading network, there are also some European countries, such as Spain, Italy, the Netherlands, Norway, Switzerland, etc. The renewable energy industry in these countries developed early and accumulated certain capital and technical experience, but due to the constraints of environment and resource endowment, they each showed different advantages. Northern European countries such as Finland, Norway and Sweden have high latitude and lack solar energy resources, so they mainly use wind energy, water energy and biomass energy. Sweden and Denmark

Table 4. Distribution of core-edge countries in the global renewable energy product trading network in 2018.

\begin{tabular}{|c|c|c|}
\hline Product Series & & Country \\
\hline \multirow{3}{*}{$\begin{array}{l}\text { Solar energy } \\
\text { products }\end{array}$} & Core states & China, Japan, the United States, Germany, Korea, Singapore (6) \\
\hline & $\begin{array}{l}\text { Semi-marginal } \\
\text { country }\end{array}$ & $\begin{array}{c}\text { Australia, Canada, Chile, Czech Republic, Denmark, Switzerland, Finland, France, the } \\
\text { United Kingdom, Brazil, Italy, Austria, Belgium, Mexico, Malaysia, Netherlands, Norway, } \\
\text { Philippines, Poland, Russia (20) }\end{array}$ \\
\hline & Peripheral countries & Saudi Arabia, Spain, Sweden, Thailand, Turkey, India, South Africa (7) \\
\hline \multirow{3}{*}{$\begin{array}{l}\text { Hydro energy } \\
\text { products }\end{array}$} & Core states & Germany, China, The United States, Australia, Belgium, Canada (6) \\
\hline & $\begin{array}{l}\text { Semi-marginal } \\
\text { country }\end{array}$ & $\begin{array}{l}\text { Chile, Switzerland, Czech Republic, Austria, Denmark, Brazil, Finland, France, the United } \\
\text { Kingdom, Spain, Italy, Japan, Korea, Mexico, Malaysia, Netherlands, Norway, Philippines, } \\
\text { Poland, Russia (20) }\end{array}$ \\
\hline & Peripheral countries & Saudi Arabia, Singapore, Sweden, Thailand, Turkey, India, South Africa (7) \\
\hline \multirow{3}{*}{$\begin{array}{l}\text { Wind energy } \\
\text { products }\end{array}$} & Core states & Germany, China, The United States, Japan, France, the United Kingdom, Denmark (7) \\
\hline & $\begin{array}{l}\text { Semi-marginal } \\
\text { country }\end{array}$ & $\begin{array}{l}\text { Sweden, Belgium, Czech Republic, Switzerland, Netherlands, Finland, Spain, Italy, Korea, } \\
\text { Mexico, Norway, Austria, Russia, Malaysia, Sweden, Turkey, India, Singapore, Thailand (19) }\end{array}$ \\
\hline & Peripheral countries & Chile, Philippines, Poland, Saudi Arabia, South Africa, Canada, Brazil, Australia (8) \\
\hline \multirow{3}{*}{$\begin{array}{l}\text { Biomass energy } \\
\text { products }\end{array}$} & Core states & $\begin{array}{c}\text { Italy, Japan, Korea, China, Czech Republic, France, the United Kingdom, Germany, } \\
\text { The United States (9) }\end{array}$ \\
\hline & $\begin{array}{l}\text { Semi-marginal } \\
\text { country }\end{array}$ & $\begin{array}{c}\text { Canada, Denmark, Brazil, Finland, Switzerland, Chile, Spain, Australia, Austria, Belgium, } \\
\text { Mexico, Malaysia, Netherlands, Norway, Poland, Sweden, Turkey (17) }\end{array}$ \\
\hline & Peripheral countries & Singapore, Philippines, Russia, Saudi Arabia, Thailand, India, South Africa (7) \\
\hline \multirow{3}{*}{$\begin{array}{l}\text { Geothermal en- } \\
\text { ergy products }\end{array}$} & Core states & Italy, Japan, China, France, The United States, Germany (6) \\
\hline & $\begin{array}{l}\text { Semi-marginal } \\
\text { country }\end{array}$ & $\begin{array}{l}\text { Belgium, Canada, Chile, Czech Republic, Denmark, Brazil, Finland, Switzerland, the United } \\
\text { Kingdom, Spain, Australia, Austria, Korea, Mexico, Malaysia, Netherlands, Norway (17) }\end{array}$ \\
\hline & Peripheral countries & $\begin{array}{l}\text { Philippines, Poland, Russia, Saudi Arabia, Singapore, Sweden, Thailand, Turkey, India, } \\
\text { South Africa (10) }\end{array}$ \\
\hline \multirow{3}{*}{$\begin{array}{l}\text { Ocean energy } \\
\text { products }\end{array}$} & Core states & Italy, Germany, China, The United States, Japan, Korea (6) \\
\hline & $\begin{array}{l}\text { Semi-marginal } \\
\text { country }\end{array}$ & $\begin{array}{l}\text { Belgium, Canada, Chile, Switzerland, Czech Republic, Austria, Denmark, Brazil, Finland, } \\
\text { France, the United Kingdom, Spain, Australia, Mexico, Malaysia, Netherlands, Norway, } \\
\text { Philippines, Poland, Singapore (20) }\end{array}$ \\
\hline & Peripheral countries & Russia, Saudi Arabia, Sweden, Thailand, Turkey, India, South Africa (7) \\
\hline
\end{tabular}

Note: Resulted from the analysis of computing core-edge degree. 
Table 5. QAP correlation analysis results of influencing factors of renewable energy product trade network.

\begin{tabular}{|c|c|c|c|c|c|c|}
\hline Product type & Solar energy & Wind energy & $\begin{array}{c}\text { Hydro } \\
\text { energy }\end{array}$ & $\begin{array}{c}\text { Geothermal } \\
\text { energy }\end{array}$ & Biomass energy & Ocean energy \\
\hline \multirow{2}{*}{$\mathrm{R}$} & $\begin{array}{l}0.643^{* * *} \\
(0.002)\end{array}$ & $\begin{array}{l}0.408^{* *} \\
(0.012)\end{array}$ & $\begin{array}{l}0.296^{* *} \\
(0.012)\end{array}$ & $\begin{array}{c}0.449^{* *} \\
(0.014)\end{array}$ & $\begin{array}{c}0.527^{* * *} \\
(0.001)\end{array}$ & $\begin{array}{c}0.342^{* *} \\
(0.010)\end{array}$ \\
\hline \multirow{2}{*}{$\mathrm{G}$} & $0.103^{* *}$ & $0.132^{* *}$ & $0.166^{* * *}$ & $0.180^{*}$ & $0.139^{* *}$ & $0.284^{* * *}$ \\
& $(0.039)$ & $(0.031)$ & $(0.000)$ & $(0.068)$ & $(0.020)$ & $(0.002)$ \\
\hline $\mathrm{T}$ & $0.354^{* *}$ & $0.503^{* * *}$ & $0.305^{* *}$ & $0.406^{* *}$ & $0.403^{* * *}$ & $0.461^{* *}$ \\
& $(0.024)$ & $(0.004)$ & $(0.026)$ & $(0.044)$ & $(0.008)$ & $(0.015)$ \\
\hline $\mathrm{A}$ & $0.274^{* *}$ & $0.216^{*}$ & $0.386^{* *}$ & $0.145^{* *}$ & $0.194^{*}$ & $0.121^{* * *}$ \\
& $(0.038)$ & $(0.054)$ & $(0.042)$ & $(0.070)$ & $(0.056)$ & $(0.002)$ \\
\hline
\end{tabular}

Note: $* * * * *$, and $*$ represent significant at $1 \%, 5 \%$, and $10 \%$ confidence levels, respectively

are global leaders in both technology and scale. And Spain, Italy, France and other countries are mainly solar, wind power generation. Their international competitiveness in the renewable energy industry is more derived from the "export" of technological level and R\&D management experience. The rest of the semimarginal countries are Asian countries such as India, Malaysia, Vietnam, and Thailand. These countries are located near the equator and have sufficient sunshine. Ocean energy resources are abundant, thus they gradually realize the transition to half-edge on solar energy, water energy and wind energy products. However, due to the lack of technology, the main production is processing and manufacturing, which has not yet formed a competitive advantage. The core products of renewable energy also rely on imports to meet the requirements.

On the periphery are Russia and Canada, as well as Australia, Brazil, South Africa and Saudi Arabia. They have abundant and high-quality traditional energy, so they have less urgent need to develop the renewable energy industry. Although Russia is rich in wind and solar energy resources, but fossil energy still occupies a dominant position in the energy consumption structure. Brazil has been focusing on R\&D and production of renewable energy since the Middle East oil crisis. It is still at the edge of the renewable energy product trading network. However, it has gradually risen to the rank of semi-marginal countries in biomass energy products. Brazil has abundant hydro power resources, it can be expected that Brazil will vigorously develop new energy product technologies. Meanwhile, such as Singapore and the Philippines, are mostly marginalized in the trade of renewable energy products. Among them, nearly $80 \%$ of Singapore's electricity fuel comes from imported natural gas. Although it has abundant marine resources, most coastal areas are only used as ports and waterways, which limited the application of marine energy technology. In addition, the country has almost no water and geothermal energy resources. The Philippines is currently in the early stages of development, mainly using palm residue and rice husks as biomass energy and using ocean energy tides to generate electricity. The lack of popularization of products and the lack of manufacturing technology make it a marginal position in product export trade.

\section{Analysis of Improving Path - Based on QAP Theory QAP Correlation Analysis}

In order to explore the reasons for the formation of the trade network of renewable energy products, this paper conducts a QAP matrix correlation analysis of the factors influencing the trade volume of renewable energy products in 2018 .

It can be seen from Table 5 that economic scale (R), geographic proximity $(\mathrm{G})$, technical elements (T), and regional trade linkages (A) will have an impact on the formation of a renewable energy product trading network. The significance of each factor at the $1 \%$ and $5 \%$ confidence levels is high, indicating that the factors considered from the four dimensions will have a more significant impact on the trade of renewable energy products. Next, QAP regression analysis was carried out to observe the effect of multiple explanatory variable matrices on an explanatory variable matrix.

\section{QAP Regression Analysis}

Using the QAP regression analysis method to comprehensively consider the above influencing factors, we can see the magnitude of the impact of each explanatory variable on the trade volume of different products.

It can be seen from the regression results that the economic scale (R) has a significant impact on the formation of each product trade network. It is the basis and important guarantee for the formation of industrial competitive advantage and stable export capacity. No matter what kind of product, from $R \& D$, production, sales to maintenance of the schedule requires a lot of financial support. Secondly, geographical proximity (G) also has a significant impact on the trade of renewable energy products, especially solar energy, wind energy and water energy products, these products contain large parts. Therefore, the closer the geographical location is, the more favorable it is for the import and export trade of products between different countries. Technology 
Table 6. QAP regression analysis results of influencing factors of renewable energy products trade network.

\begin{tabular}{|c|c|c|c|c|c|c|}
\hline Product type & Solar energy & Wind energy & $\begin{array}{c}\text { Hydro } \\
\text { energy }\end{array}$ & $\begin{array}{c}\text { Geothermal } \\
\text { energy }\end{array}$ & Biomass energy & Ocean energy \\
\hline $\mathrm{R}$ & $0.436^{* *}$ & $0.521^{*}$ & $0.459^{* *}$ & $0.529^{*}$ & $0.384^{* *}$ & $0.369^{* *}$ \\
\hline $\mathrm{G}$ & $0.274^{*}$ & $0.326^{* *}$ & $0.354^{* * *}$ & $0.232^{*}$ & $0.132^{*}$ & $0.214^{*}$ \\
\hline $\mathrm{T}$ & $0.397^{* * *}$ & $0.474^{* *}$ & $0.433^{* *}$ & $0.627^{*}$ & $0.464^{* * *}$ & $0.538^{*}$ \\
\hline $\mathrm{A}$ & $0.167^{* *}$ & $0.184^{*}$ & $0.143^{*}$ & $0.187^{* *}$ & $0.215^{*}$ & $0.118^{*}$ \\
\hline $\mathrm{R}^{2}$ & 0.327 & 0.346 & 0.322 & 0.149 & 0.274 & 0.168 \\
\hline Adj-R & 0.340 & 0.349 & 0.325 & 0.152 & 0.365 & 0.197 \\
\hline
\end{tabular}

Note: $* * * * *$, and $*$ represent significant at $1 \%, 5 \%$, and $10 \%$ confidence levels, respectively

endowment $(\mathrm{T})$ has a particularly significant impact on renewable energy products. Whether solar products convert light energy and heat energy into electric energy, water energy and wind energy convert kinetic energy into electric energy, and biomass energy convert heat energy, electric energy, geothermal energy and Marine energy, all of which need to be realized by technology. Among them, geothermal energy products are more significantly affected by technical factors than other products, followed by Marine energy products, so there are bound to be many technical difficulties to be overcome in the conversion of these forms of energy. The signing or not of the trade agreement (A) mainly takes into account primarily the impact of the degree of regional free trade on the formation of trade networks in renewable energy. The signing and construction of trade agreements will not only produce the economic significance of cooperation, energy promotes the free flow of commodities and capital, but also bring a certain value of technological exchange through technological cooperation.

\section{Conclusions}

This article used social network analysis technology to build a global trade network of renewable energy products in 33 major countries in 2018, analyzed the structural characteristics and used QAP to quantify the factors that affect the formation of the trade network. The conclusion is as follows:

First, these countries have different roles in the trade network due to the different status of industrial division and international division of labor. Among them, the United States, Germany, the Netherlands, China, Japan and other countries are the suppliers of products, which were reflected in their large export and intensity values. South Africa, the Philippines, Vietnam, Thailand and other countries are the demanders, they usually act as parts and components processing agents, and the development of renewable energy equipment mostly depends on imports. From the perspective of the overall evolutionary process, the trade ties between countries are getting closer.
Secondly, from the calculation results, it can be seen that Chile, Thailand, the Philippines, Denmark and Saudi Arabia have a high degree of closeness centrality. They are distributed in South America, Central Asia, Southeast Asia and Northern Europe, and seem to exist as connecting nodes between the various plates. This obviously depends on the high degree of transmission in the surrounding countries. In fact, the direct transmission efficiency between them and the core country is low. This also confirms the limitation of measuring the status of the international division of labor only by the amount of trade. China, the United States, Germany, Japan, the Republic of Korea, the Netherlands and other countries are obviously core countries in terms of betweenness centrality, in the entire trade network of renewable energy products. They have significant production control capabilities, which are reflected in advanced manufacturing technology, mass production and international recognition of products. However, there is still a definite gap between China and developed countries in terms of closeness and betweenness centrality. In the division of labor in the value chain, it is necessary to enhance the core competitiveness of products, develop upstream, and enhance the breadth and depth of division of labor and cooperation.

Third, Germany, China, and the United States have the most important core positions and advantages. They have shown outstanding international competitiveness in solar and wind energy products. At the same time, industrial powers such as Japan, the United Kingdom and France are in their respective areas of advantage. It also plays a central role. Due to the early start of the renewable energy industry, extensive application, advanced technology and management experience, most European countries are in a core or semi-peripheral position. Developing and emerging economies are gradually transitioning to semi-peripheral countries. These countries have great potential for the development of renewable energy industries. However, due to their weak industrial foundation, they lack the driving force and conditions for the development of new energy. There are still some traditional energy-rich countries, such as Russia, where natural gas and oil still 
dominate, so they are temporarily marginalized in the trade network of renewable energy products. In such a general environment, although China has made certain achievements in the development of the renewable energy industry, its energy consumption structure still has a long way to go in achieving a clean and efficient transformation.

Finally, through QAP correlation analysis and matrix regression analysis, it can be seen that the formation of the renewable energy product trade network is affected by the economic scale, geographic location, technological endowment and regional trade correlation among node countries. At the same time, due to different product forms and development bases, various factors have different effects on different products. In general, all factors have a significant positive correlation with the trade network. Therefore, a country can break through geographical restrictions by reducing transportation costs, continuously increase economic scale, give full play to the comparative advantages of technological element endowments, and deepen regional trade cooperation, so as to explore an effective path for the development and promotion of renewable energy industry trade.

\section{Policy Implications}

China's trade in renewable energy products has ranked among the top in the world. However, in the global trade network, there is a huge gap between China and the powerhouse of the renewable energy industry, and there is still much room for improvement in product production and export. We should identify and maintain a comparative advantage in the global renewable energy product trade network, and expand its international market share. (1) Determine the key factors for forming a trading network of different products, and formulate a development plan for the renewable energy industry, increase capital and technology investment in new renewable energy sources such as geothermal energy and ocean energy, and popularize biomass energy more deeply. (2) For large-scale energy development projects, enterprises should expand financing channels and establish clear technical standards, industry standard systems and management systems. It is also important to form our own core competitiveness. We should learn technology development and production experience from advanced countries, and continuously improve product quality and production capacity, so as to gain a core position in the international trade network. (3) We must accelerate the transformation and upgrading of the domestic energy consumption structure, and realize a model of energy saving, emission reduction, clean and efficient energy consumption. Take advantage of the opportunity to promote the transformation to guide the production and manufacture of domestic renewable energy equipment, and help national manufacturing enterprises to "Go Global" through policies such as tax relief and preferential interest rate subsidies. (4) At the trade level, we can expand trade cooperation with some underdeveloped countries or regions and national renewable energy industries. Understand the status of China's renewable energy products in the international trade network, analyze the dynamic evolution of the trade network, to grasp the future development trend, and find a broader space for trade cooperation.

\section{Acknowledgements}

This study was supported by the Social Science Project of Hebei, China - Research on the Comprehensive Energy Utilization System of Xiong'an New Area based on the sharing Economy Model (HB19YJ011).

\section{Conflict of Interest}

The authors declare no conflict of interest.

\section{References}

1. FU J. The Status of International Competitiveness and Development Approaches of China's PV Industry. Journal of Hebei University (Philosophy and Social Science). 38 (02), 53, 2013.

2. SUN J. Research on International Trade Competitiveness of Solar Energy Photovoltaic Industry of China. Price Monthly. 12 (07), 32, 2017.

3. JHA V. Trade Flows, Barriers and Market Drivers in Renewable Energy Supply Goods: The Need to Level the Playing Field; ICTSD Trade and Environment Issue Paper 10; International Centre for Trade and Sustainable Development: Geneva, Switzerland, 2009.

4. SHUAI J.C., JIN H., LENG Z.H., WANG Z H., SHI Z.Y. Research on the International Competitiveness of China's Renewable Energy Products in the Context of the Belt and Road Initiative. China Soft Science. 07, 21, 2018.

5. MING L. Evaluation method of industrial export competitiveness based on the variance: With an example of wind energy industry[C]// INTERNATIONAL CONFERENCE OF NUMERICAL ANALYSIS AND APPLIED MATHEMATICS 2015 (ICNAAM 2015). AIP Publishing LLC, 2016.

6. LIU M. New Energy Industry International Trade Relations and China's Current Situation - Based on the Space Gravity Model. China Business and Market. 29 (08), 94, 2015.

7. BOHRINGER C., RUTHERFORD T.F. Carbon Taxes with Exemptions in an Open Economy: A General Equilibrium Analysis of the German Tax Initiative [J]. Journal of Environmental Economics \& Management. 32 (2), 189, 1997.

8. KIM K.N., KIM Y.B. Role of policy in innovation and international trade of renewable energy technology: Empirical study of solar PV and wind power technology. Renewable and Sustainable Energy Reviews. 44, 717, 2015. 
9. WANG Z.W. Analysis and evaluation of China's regional competitiveness of solar photovoltaic industry. Southwestern University of Finance and Economics. 2012.

10. SNYDER D., KICK E.L. Structural position in the world system and economic growth, 1955-1970: A multiplenetwork analysis of transnational interactions. American Journal of Sociology. 84, 1096, 1979.

11. SERRANO M A., BOFUNA M. Topology of the World Trade Web. Phys Rev E Stat Nonlin Soft Matter Phys, 68 (2), 015101, 2003.

12. FAGIOLO G., RDYES J., SCHIAVO S. The evolution of the world trade web: a weighted-network analysis. Journal of Evolutionary Economics, 20 (4), 479, 2010.

13. BASKARAN T., BIOECHL F., BRUECK T., FABIAN J.THEIS. The Heckscher-Ohlin model and the network structure of international trade. International Review of Economics \& Finance, 20 (2), 135, 2011.

14. MA S.Z., REN W.W., WU G.J. The Characteristics of a Country's Agricultural Trade Network and its Impact on the Division of Labor in the Global Value Chain - Based on the perspective of social network analysis. Management World. 03, 60, 2016.
15. DONG G.G., QING T., DU R.J., WANG C., Li R.Q., WANG M.G., TIAN L.X., CHEN L., ANDRE L.M. VILELA., H. Eugene Stanley. Complex Network Approach for the Structural Optimization of Global Crude Oil Trade System. Journal of Cleaner Production. 251, 2020.

16. XI X., ZHOU J.S., GAO X.Y., LIU D.H., ZHENG H.L., SUN Q.R. Impact of changes in crude oil trade network patterns on national economy. Energy Economics. 84, 104490, 2020.

17. GUAN Q., AN H.Z., HAO X.Q., JIA X.L. The impact of countries' roles on the international photovoltaic trade pattern: the complex networks analysis. Sustainability. 8 (4), 313, 2016.

18. JI J.W. The Analysis of the international PV Trade Competition pattern and PV Market of China Based on Complex Network Theory. Zhenjiang, Jiangsu University, 2016.

19. Zhang G.P., DUAN H.B. How does international trade network affect multinational diffusion of wind power technology? Journal of Cleaner Production. 276, 123245, 2020. 